\title{
BMJ Open Pain in patients with COPD: a systematic review and meta-analysis
}

\author{
Eléonore F van Dam van Isselt, ${ }^{1}$ Karin $\mathrm{H}$ Groenewegen-Sipkema, ${ }^{2}$ \\ Monica Spruit-van Eijk, Niels H Chavannes, ${ }^{1,1}$ Margot W M de Waal, ${ }^{1}$ \\ Daisy J A Janssen, ${ }^{3}$ Wilco P Achterberg ${ }^{1}$
}

To cite: van Dam van Isselt EF, GroenewegenSipkema KH, Spruit-van Eijk M, et al. Pain in patients with COPD: a systematic review and meta-analysis. BMJ Open 2014:4:e005898. doi:10.1136/bmjopen-2014005898

- Prepublication history and additional material is available. To view please visit the journal (http://dx.doi.org/ 10.1136/bmjopen-2014005898)

Received 13 June 2014 Revised 29 August 2014 Accepted 3 September 2014

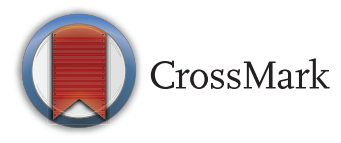

${ }^{1}$ Department of Public Health and Primary Care, Leiden University Medical Center, Leiden, The Netherlands ${ }^{2}$ Pulmonary Department, Deventer Hospital, Deventer, The Netherlands

${ }^{3}$ Department of Research and Education, $\mathrm{ClRO}+$, Centre of Expertise for Chronic Organ Failure, Horn,

The Netherlands

\section{Correspondence to}

Eléonore $F$ van Dam van

Isselt; E.F.vanDamvanlsselt@ lumc.nl

\section{ABSTRACT \\ Objectives: To systematically investigate the prevalence of pain, factors related with pain and pain management interventions in patients with chronic obstructive pulmonary disease (COPD).}

Design: Systematic review and meta-analysis.

Data sources and study eligibility criteria:

PubMed (MEDLINE), EMBASE, CINAHL and PsychINFO from 1966 to December 2013. Studies were included if they presented clinical data on pain or symptom burden in patients with COPD, or pain as a domain of quality of life (QoL). All types of study designs were included.

Results: Of the 1571 articles that were identified, 39 met the inclusion criteria and were included in this review. Fourteen studies focused on pain and symptom burden (including pain) in patients with COPD and 25 studies focused on QoL using a questionnaire that included a separate pain domain. Reported pain prevalence in high-quality studies ranged from 32 to $60 \%$. Included studies report that pain is more prevalent in patients with COPD compared to participants from the general population. Comorbidity, nutritional status, QoL and several symptoms were related to pain. None of the included studies reported a significant relationship between lung function and pain prevalence or severity. However, studies investigating pain in patients with moderate COPD reported higher pain prevalence compared to studies in patients with severe of very severe COPD.

Conclusions: Although literature on this topic is limited and shows substantial heterogeneity, pain seems to be a significant problem in patients with COPD and is related to several other symptoms, comorbidity and QoL. Data synthesis suggests that pain is more prevalent in patients with moderate COPD compared to patients with severe or very severe COPD. Further research is needed and should focus on determining a more accurate pain prevalence, investigating the relationship between pain prevalence, disease severity and comorbidity and explore implementation and efficacy of pain management interventions in patients with COPD.

\section{INTRODUCTION}

Chronic obstructive pulmonary disease (COPD) is a chronic, usually progressive

\section{Strengths and limitations of this study}

- This is the first systematic review on pain in patients with chronic obstructive pulmonary disease (COPD).

- A broad search strategy was used, to minimise the risk of missing any relevant published studies.

- Literature on pain in patients with COPD is limited and included studies that showed great heterogeneity, therefore confounding and selection bias are likely to occur.

- Owing to the search strategy that was used, data on pain as a subdomain of quality of life may not be complete.

airway disease. Both the prevalence and disease severity of COPD are strongly related to age and worldwide, the rate of related morbidity and mortality is rising. ${ }^{1}$ COPD represents a major burden for individual patients, healthcare systems and society in terms of healthcare costs. ${ }^{2}$ As the disease progresses, health status becomes increasingly impaired. Especially in advanced COPD, patients suffer from high symptom burden, impaired functional capacity and poor quality of life (QoL). ${ }^{34}$

Well-known symptoms in COPD are dyspnoea, cough and wheezing, whereas other symptoms such as fatigue, nausea and insomnia are also frequently reported..$^{5}$ Recent literature indicates that pain is also a significant symptom in patients with COPD. Two systematic reviews on patients with end-stage $\mathrm{COPD}^{6}{ }^{7}$ reported prevalences of pain of $21-77 \%$. Both these reviews reported only on studies including patients with advanced or terminal disease or studies on palliative care in patients with very severe COPD. Less is known about pain in patients with mild-to-moderate disease. In a cross-sectional study on pain in patients with moderate-tosevere COPD, HajGhanbari et $a l^{8}$ reported that pain is more prevalent among individuals with COPD compared with healthy adults. 
Bentsen et at found similar results, reporting pain in $45 \%$ of the patients with moderate COPD compared with $34 \%$ in the general population. Other questions remain about pain in COPD. For example, the relationship with disease severity and comorbidity remains unclear ${ }^{8}$ and information on the causes and characteristics of pain, and how pain influences functional capacity and QoL, is scarce. ${ }^{8}{ }^{9}$ There are several factors related to COPD that may contribute to a higher pain prevalence in patients with COPD. The systemic inflammatory process, which activates cytokines, may generate chronic and neuropathic pain. Musculoskeletal disorders and comorbidities (including mechanical limitations of chest wall movement due to hyperinflation and osteoporosis) are also considered possible causes of pain in patients with COPD and inactivity may aggravate common age-related comorbidities such as osteoarthritis and low back pain. ${ }^{8}$ Improving knowledge on aetiology, characteristics, correlations and impact of pain is important and necessary to improve pain recognition and pain treatment in patients with COPD. It is likely that adequate pain recognition and treatment is important in improving QoL, exercise tolerance and lifelong adherence to physical activity in patients with COPD. Thus, pain seems to be a relevant but poorly understood problem in patients with COPD. Therefore, the aim of this review is to systematically describe and investigate pain in patients with COPD. More specifically, to examine the prevalence of pain and factors related with pain and to identify interventions that may reduce pain in patients with COPD.

\section{METHODS}

\section{Electronic searches}

We conducted a systematic search using MEDLINE/ PubMed (from 1966 to December 2013), EMBASE (from 1980 to December 2013), CINAHL (from 1981 to December 2013) and PsychINFO (from 1980 to December 2013) using the following groups of keywords:

1. Pain, pains, Pain Measurement, Analgesics, analgesic (PubMed), pain, pain assessment, analgesia, analgesic (EMBASE), Pain, analgesia, analgesic (CINAHL), Pain, Aphagia, Back Pain, Chronic Pain, Headache, Myofascial Pain, Neuralgia, Neuropathic Pain, Somatoform Pain Disorder, Analgesia, analgesic (PsychINFO).

2. Pulmonary Disease, Chronic Obstructive, COPD, Lung Diseases, Obstructive, chronic bronchitis, chronic obstructive airway disease, chronic airway obstruction, chronic airway obstructions, COAD, chronic airflow obstruction, chronic airflow obstructions, Pulmonary Emphysema.

Keywords were entered using controlled terms (eg, Medical Subject Headings in Medline) and as free-text word. Within each group the keywords were combined using 'OR' and the two groups were combined using 'AND' (see online supplementary file 1). No language or other restrictions were applied. Reference lists from included studies and reviews were searched by hand to identify additional articles. All articles that were identified by the electronic search were put into a reference database (Reference Manager V.12.0).

\section{Selection of studies}

Articles that reported original data on pain in patients with COPD, or assessed pain as a domain of QoL in patients with COPD, were considered eligible. We included all types of study designs (cross-sectional, longitudinal, prospective/retrospective, qualitative/quantitative design). Articles without an (English) abstract, reviews, editorials, conference abstracts and case reports were excluded. Two members of the review team (EFvDvI and KG) independently assessed the titles and abstracts of all potentially relevant publications that were identified from the search. Decisions of the two reviewers about inclusion/exclusion were compared and, in case of disagreement, were resolved by asking a third reviewer (DJAJ) and to achieve consensus. Subsequently, the same two reviewers evaluated the full text of all potentially eligible articles. Decisions about inclusion and exclusion were again compared and, in case of disagreement, resolved by asking the third reviewer in order to achieve consensus.

\section{Data extraction and quality assessment}

Details on study design, patients, setting and outcome were recorded by two independent reviewers (EFvDvI and $\mathrm{KG}$ ). For each study the following items were recorded: author, journal, year of publication, country of origin, design and aim of the study, setting, inclusion and exclusion criteria, response rate, number of patients, patient characteristics (age, forced expiratory volume in $1 \mathrm{~s}$ as $\%$ of predicted value $\left(\mathrm{FEV}_{1} \%\right.$ predicted), Global Initiative for Chronic Obstructive Lung Disease (GOLD) grade, and gender), pain and QoL instrument used, reported pain prevalence or mean score on the pain domain of the QoL instrument, correlations, limitations and conclusions.

All included articles were ranked for quality according to the Mixed Method Appraisal Tool (MMAT). ${ }^{10}$ The MMAT has recently been developed for the appraisal stage of systematic literature reviews that include quantitative, qualitative and mixed methods studies. The MMAT has proven to be an effective and practical quality assessment tool for mixed method review studies. ${ }^{10}$ The MMAT consists of four criteria for the appraisal of quantitative (descriptive, randomised and non-randomised) and qualitative studies. Hence, each study design is judged within its methodological domain (table 1). The MMAT scores range from $100 \%$ (all four criteria are met) to $25 \%$ (one criterion is met). In the present review, quality assessment scores were calculated for all included studies. Ranking according to the MMAT was conducted by two independent reviewers (EFvDvI and KG) and any disagreement in the MMAT scores was resolved by discussion or by asking a third reviewer (DJAJ) for advice to reach consensus. 
Types of mixed methods study

components or primary studies Methodological quality criteria (see tutorial for definitions and examples)

Screening questions (for all types) Are there clear qualitative and quantitative research questions (or objectives ${ }^{\star}$ ), or a clear mixed

Yes No Can't tell Comments

methods. question (or objectives ${ }^{\star}$ ?

Do the collected data allow address the research. question (objective)? Eg. consider whether the

follow-up period is long enough for the outcome to occur (for longitudinal studies or study

components)

1. Qualitative

Further appraisal may be not feasible or appropriate when the answer is 'No' or 'Can't tell' to one or both screening questions.

1.1. Are the sources of qualitative data (archives, documents, informants, observations) relevant to address the research question (objective)?

1.2. Is the process for analysing qualitative data relevant to address the research question (objective)?

1.3. Is appropriate consideration given to how findings relate to the context, eg, the setting, in which

the data were collected?

1.4. Is appropriate consideration given to how findings relate to researchers' influence, eg, through their interactions with participants?

2. Quantitative randomised controlled (trials)

2.1. Is there a clear description of the randomisation (or an appropriate sequence generation)?

2.2. Is there a clear description of the allocation concealment (or blinding when applicable)? 2.3. Are

there complete outcome data ( $80 \%$ or above)?

2.4. Is there low withdrawal/drop-out (below 20\%)?

3. Quantitative non-randomised 3.1. Are participants (organisations) recruited in a way that minimises selection bias?

3.2. Are measurements appropriate (clear origin, or validity known, or standard instrument: and

absence of contamination between groups when appropriate) regarding the exposure intervention and outcomes?

3.3. In the groups being compared (exposed vs non-exposed: with intervention vs without; cases vs

controls), are the participants comparable, or do researchers take into account (control for) the

difference between these groups?

3.4. Are there complete outcome data ( $80 \%$ or above), and, when applicable, an acceptable response rate $(60 \%$ or above), or an acceptable follow-up rate for cohort studies (depending on the duration of follow-up)?

4. Quantitative descriptive

4.I. Is the sampling strategy relevant to address the quantitative research question (quantitative aspect of the mixed methods question)?

4.2. Is the sample representative of the population understudy?

4.3. Are measurements appropriate (clear origin, or validity known, or standard instrument)? 4.4. Is there an acceptable response rate $(60 \%$ or above)?

5.1. Is the mixed methods research design relevant to address the qualitative and quantitative research questions (or objectives), or the qualitative and quantitative aspects of the mixed methods question (or objective)?

5.2. Is the integration of qualitative and quantitative data (or results ${ }^{\star}$ ) relevant to address the research question (objective)?

5.3. Is appropriate consideration given to the limitations associated with this integration, eg,the

divergence of qualitative and quantitative data (or results ${ }^{\star}$ ) in a triangulation design?

Criteria for the qualitative component (1.1 to 1.4), and appropriate criteria for the quantitative component (2.1 to 2.4. or 3.1 to 3.4. or 4.1 to 4.4), must be also applied

${ }^{*}$ These two items are not considered as double-barreled items since in mixed methods research, (1) there may be research questions (quantitative research) and or research objectives (qualitative research), and (2) data may be integrated, and/or qualitative findings and quantitative results can be integrated. 


\section{Data synthesis and meta-analysis}

A meta-analysis was performed concerning the Short-Form health survey (SF)-36_Bodily Pain data.

The SF-36 is a widely used, self-administered, reliable and valid instrument to assess generic health-related QoL. ${ }^{11}$ The SF-36 consists of 36 items divided into eight subdomains. The score of each subdomain ranges from 0 to 100 , with 100 representing the best quality of life. The questionnaire contains two questions related to pain: the SF-36 bodily pain subdomain (SF-36_BP): 'How much bodily pain have you had during the past (4) week(s)?' (score from 0 (no pain) to 6 (very severe pain)) and 'During the past (4) week(s), how much did pain interfere with your normal work (including both work outside the home and housework)? (score from 0 (not at all) to 5 (extremely)) We performed a meta-analysis with a Forest plot using a Microsoft Excel spreadsheets, as developed by Neyeloff $e t a l .{ }^{12}$ They showed that this method produces a statistically adequate but graphically appealing forest plot summarising descriptive data. We assumed a random-effects model to calculate the mean score on the SF-36_BP item and a 95\% CI. The heterogeneity was assessed with the $Q$ statistic and the $\mathrm{I}^{2}$ index. Meta-analyses and Forest plots using a Microsoft excel spreadsheet were conducted by step-by-step guide focusing on descriptive data analysis. ${ }^{12}$ To determine the strength of the linear correlations between lung function $\left(\mathrm{FEV}_{1} \%\right.$ predicted) and pain prevalence and the SF-36_BP score, we calculated the correlation coefficient between these variables. In case of normally distributed data, Pearson correlation coefficient was calculated. In case of non-normally distributed data a non-parametric test (Spearman's test) was used. We defined statistical significance at $\mathrm{p} \leq 0.05$ (two-sided level of significance). In studies that presented only the GOLD grade distribution the mean GOLD grade was calculated and converted into a mean $\mathrm{FEV}_{1} \%$-predicted.

\section{RESULTS}

\section{Study selection and characteristics}

The electronic systematic search identified 1571 eligible citations (PubMed 1067, EMBASE 379, CINAHL 71, PsychINFO 54). Eight studies were identified using other sources. A total of 1491 citations were excluded based on title and abstract. In total, 88 articles were reviewed in detail. Reasons for exclusion are reported in the PRISMA flowchart (figure 1). Thirty-nine studies met the inclusion criteria and were included in the review (tables 2 and 3 ).

Fourteen studies focused on pain and symptom burden (including pain) in COPD ${ }^{5} \quad 9^{13-23}$ and 25 studies focused on QoL using a questionnaire that included a separate pain domain ${ }^{4-47}$ (table 2 and 3). The included studies were published between 1995 and 2013. All included studies on symptom burden in COPD were published in the past decade (2000-2013) and studies with a specific focus on pain in COPD were published in the last 5 years (figure 2).

Of the 14 articles on pain and symptom burden in COPD, three reports from Bentsen et at ${ }^{21} 22$ and two reports from Borge et $a l^{1820}$ were based on the same original research study. Ten studies were conducted at the outpatient pulmonary department of a hospital (secondary and tertiary care), one in primary care and three were population-based studies. Most studies on pain and symptom burden $(\mathrm{n}=10 ; 71 \%)$ had a cross-sectional design. The majority of the included studies on pain as a domain of QoL also used a cross-sectional design $(\mathrm{n}=17 ; 68 \%)$, seven studies used a prospective design (observational $(n=3)$ and interventional $(n=4))$ and one study used a retrospective design. Almost all studies $(n=21)$ on pain as a domain of QoL included patients with COPD recruited from an outpatient pulmonary department or hospital/intensive care unit setting (secondary and tertiary care).

\section{Quality assessment}

Of the 14 studies on pain and symptom burden in COPD, 10 had a MMAT score of $100 \%$, three scored $75 \%$ and one study scored $50 \%$ (table 2). Shortcomings in quality included insufficient response rate, ${ }^{13} 141820$ or insufficient comparability between participants. ${ }^{13}$ Of the 25 studies on pain as a subdomain of QoL, $20 \mathrm{had}$ a score of $75 \% \quad(n=14)$ or $100 \% \quad(n=6)$. The most frequent shortcoming in quality assessment was an insufficiently or not reported response rate $(n=19$; table 3$)$.

\section{Pain measurement}

Pain was measured using different instruments. Five studies on pain and symptom burden in COPD used the Brief Pain Inventory (BPI), or the body outline diagram of the BPI. ${ }^{48}$ The BPI is a self-administered questionnaire used to assess the severity of pain (scale $0-10$; cut-off points: mild pain (0-4), moderate pain: (5-6) and severe pain $(7-10))$ and the impact of pain on daily functioning (scale 0-10) in patients with chronic diseases or conditions. The BPI also contains a body diagram on which patients can indicate the location on which they experienced the most pain. ${ }^{20}{ }^{48}$ In five studies pain was not measured with a specific pain or symptom questionnaire, but a screening question was used, such as: 'Are you generally bothered with pain?'9 or 'Are you usually free of pain and discomfort?'. ${ }^{15}$ Other instruments used include: the McGill Pain Questionnaire (MPQ), the Memorial Symptom Assessment Scale (MSAS), the VOICES questionnaire and the London and Leeds Pain Survey. One study measured pain using a Visual Analogue Scale (VAS). ${ }^{5}$

Pain as a subdomain of QoL was measured using five different instruments: the SF-36 ( $\mathrm{n}=19)$, the EuroQol-5 Dimensions (EQ-5D; $\mathrm{n}=3$ ), the Nottingham Health Profile (NHP; $n=3$ ), the Health Status Questionnaire (HSQ $n=1$ ) and the Duke Health Profile (DHP; n=1). 


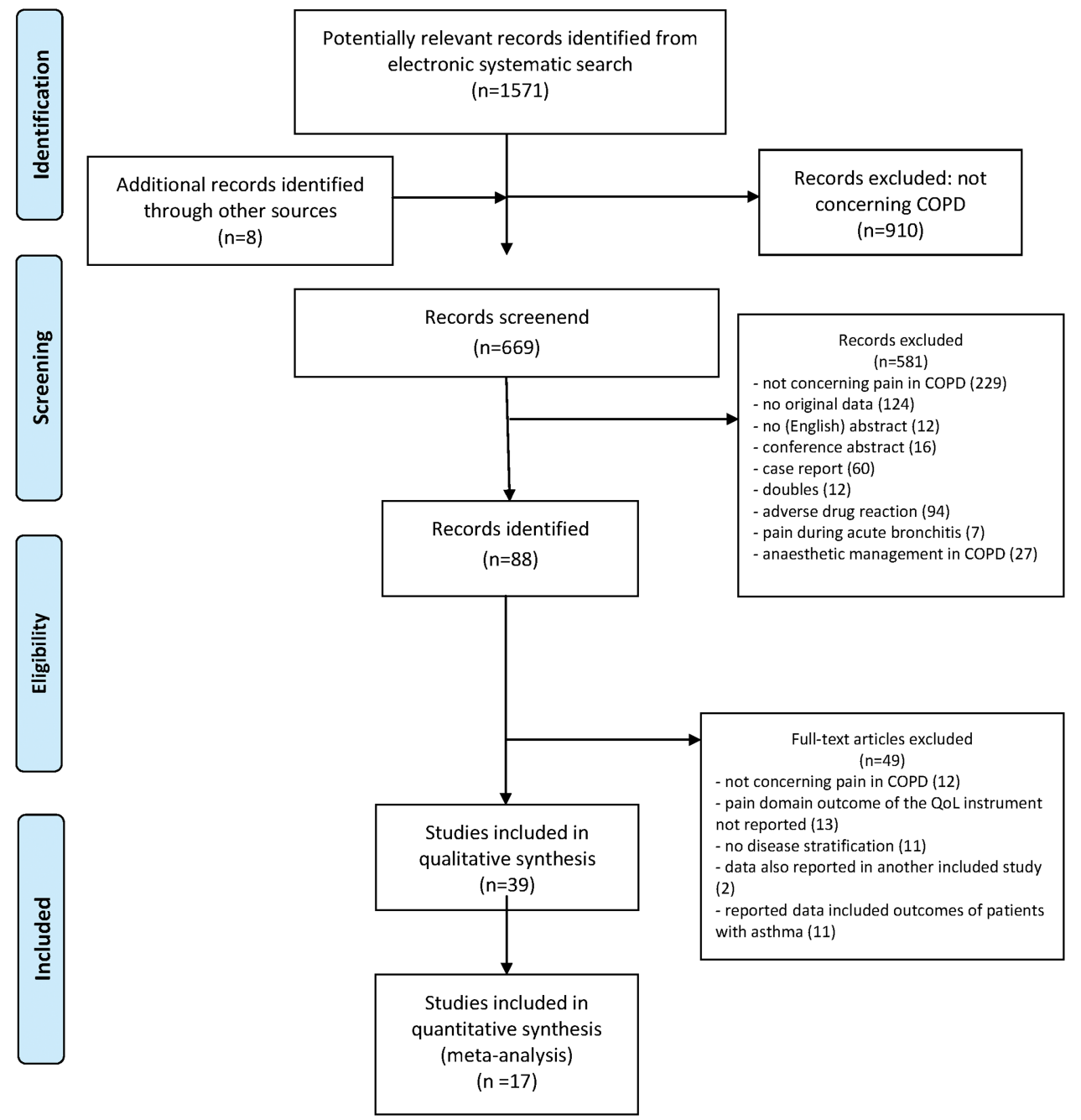

Figure 1 Flow diagram of the inclusion of studies (according to the PRISMA guidelines).

\section{Prevalence of pain}

Of the 14 studies on pain and symptom burden, 11 reported the prevalence of pain: range from $21 \%$ to $72.1 \%$ (figure 3 ). Studies on prevalence of pain differed in design, setting and patient characteristics. Mean age was 57.9-76.8 years and mean $\mathrm{FEV}_{1} \%$ predicted ranged from $21 \%$ to $48 \%$. Three studies did not report the mean $\mathrm{FEV}_{1} \%$ predicted or the GOLD grade of the included patients. The MMAT scores of the studies that reported pain prevalence ranged from $50 \%$ to $100 \%$. The reported pain prevalence of the studies with a MMAT score of $100 \%$ ranged from $32.4 \%$ to $59.8 \%$ (figure 3 ). Five studies investigated the prevalence of pain in patients with COPD compared to participants from the general population, ${ }^{8} 9$ patients with other chronic diseases ${ }^{5} 23$ or patients with lung cancer. ${ }^{13}$ Bentsen et a ${ }^{\ominus}$ found a pain prevalence in patients with COPD of $45 \%$ compared to $34 \%$ in the general population $(\mathrm{p}=0.02)$ and HajGhanbari et $a l^{8}$ reported that patients with COPD reported 2.5 times more pain and 3.7 times more interference of pain with daily activities, compared to healthy people. Roberts et al also reported that a higher pain prevalence in patients with COPD compared to patients with other chronic diseases
( $59.8 \%$ vs $51.7 \%$; $\mathrm{p}=0.001$ ), but in the study conducted by Janssen $e t$ al, patients with chronic heart failure reported more pain than patients with COPD (48.8\% vs $32.4 \%$, $\mathrm{p}=0.05$ ).

Of all included studies, 19 used the SF-36, the SF-20 or the SF-8. Of these, 17 reported scores on the bodily pain domain as a mean score (SD). In four of these studies, the SF-36_BP was measured in two separate groups of patients with COPD (cases and controls). A random-effects meta-analysis on the SF-36/20/8_BP data of the 21 studies and groups of patients with COPD, showed a mean score on the SF-36_BP of 66.7 (CI 95\% 61.2; 72.2; figure 4). The three studies that used the EQ-5D showed that $45 \%,{ }^{40}$ $46 \%$ and $56 \%{ }^{41}$ of the patients with COPD reported having any problems on the subdomain pain/discomfort of the EQ-5D, respectively.

\section{Characteristics of pain}

Five studies measured pain intensity and interference using the BPI. Mean pain intensity scores ranged from 2.8 to 5.4 points (mild to moderate pain) and mean interference scores ranged from 3.6 to 5.8 points (mild to moderate interference) on a scale from 0 to 10 
Table 2 Pain and symptom burden

\begin{tabular}{|c|c|c|c|c|c|c|c|c|c|}
\hline Author & Aim & Setting and sample & $\begin{array}{l}\mathrm{N} \text { (patients } \\
\text { with COPD) }\end{array}$ & $\begin{array}{l}\text { Mean age in } \\
\text { years (SD) }\end{array}$ & $\begin{array}{l}\mathrm{FEV}_{1} \% \text { of } \\
\text { predicted (SD) }\end{array}$ & GOLD-stage & $\begin{array}{l}\text { Pain, symptom, QoL } \\
\text { instrument used }\end{array}$ & $\begin{array}{l}\text { Outcome (pain } \\
\text { prevalence) (\%) }\end{array}$ & $\begin{array}{l}\text { MMAT } \\
\text { score }\end{array}$ \\
\hline $\begin{array}{l}\text { Claessens et al }{ }^{13 *} \\
\text { USA }\end{array}$ & $\begin{array}{l}\text { To compare the course of } \\
\text { illness and patterns of care for } \\
\text { patients with non-small-cell } \\
\text { lung carcinoma (NSCLC) and } \\
\text { COPD }\end{array}$ & $\begin{array}{l}\text { Secondary care } \\
\text { Patients with severe COPD or } \\
\text { stage II of IV NSCLC, recruited } \\
\text { on admission to the hospital } \\
\text { because of acute illness/ } \\
\text { exacerbation }\end{array}$ & 1008 & $70(-)$ & - & - & $\begin{array}{l}\text { Screening question: } \\
\text { 'How much of the time } \\
\text { do you experience pain'? } \\
\text { 'How severe is the pain' }\end{array}$ & 21 & $\begin{array}{l}50 \% \\
3.1:+ \\
3.2:+ \\
\text { 3.3:- } \\
\text { 3.4:- }\end{array}$ \\
\hline $\begin{array}{l}\text { Elkington et } a l^{14 * * *} \\
\text { UK }\end{array}$ & $\begin{array}{l}\text { To assess the healthcare } \\
\text { needs of patients with COPD } \\
\text { in the last year of life }\end{array}$ & $\begin{array}{l}\text { Population based } \\
\text { Informants of COPD or } \\
\text { emphysema deaths were } \\
\text { identified by the Office for } \\
\text { National Statistics }\end{array}$ & 209 & $76.8(-)$ & - & - & VOICES & 72 & $\begin{array}{l}75 \% \\
4.1:+ \\
4.2:+ \\
4.3:+ \\
4.4:-\end{array}$ \\
\hline $\begin{array}{l}\text { Rashiq et } a l^{15 * *} \\
\text { Canada }\end{array}$ & $\begin{array}{l}\text { To determine the associations } \\
\text { of Chronic Non Cancer Pain } \\
\text { (CNCP) with a wide range of } \\
\text { factors in the biological, } \\
\text { psychological and social } \\
\text { domain }\end{array}$ & $\begin{array}{l}\text { Population based } \\
\text { Sample from data from the } \\
\text { Canadian National Population } \\
\text { Health Survey }\end{array}$ & 2289 & - & - & - & $\begin{array}{l}\text { Screening question: } \\
\text { 'Are you usually free of } \\
\text { pain and discomfort'? }\end{array}$ & 34.9 & $\begin{array}{l}100 \% \\
4.1:+ \\
4.2:+ \\
4.3:+ \\
4.4:+\end{array}$ \\
\hline $\begin{array}{l}\text { Blinderman et } a l^{16 *} \\
\text { USA }\end{array}$ & $\begin{array}{l}\text { To evaluate the pattern of } \\
\text { symptom distress and } \\
\text { investigate the relationships } \\
\text { among symptoms and } \\
\text { measures of comorbidity, } \\
\text { physical and mental } \\
\text { functioning and QoL in } \\
\text { patients with advanced COPD }\end{array}$ & $\begin{array}{l}\text { Secondary care } \\
\text { Patients identified by review } \\
\text { medical records in outpatients } \\
\text { pulmonary department }\end{array}$ & 100 & $62.2(10.5)$ & 24.4 (3.9) & - & $\begin{array}{l}\text { MSAS } \\
\text { SIP } \\
\text { MILQ }\end{array}$ & 41 & $\begin{array}{l}100 \% \\
4.1:+ \\
4.2:+ \\
4.3:+ \\
4.4:+\end{array}$ \\
\hline $\begin{array}{l}\text { Lohne et } a l^{17 \star \star \star \star} \\
\text { Norway }\end{array}$ & $\begin{array}{l}\text { To evaluate pain experiences } \\
\text { of patients with COPD }\end{array}$ & $\begin{array}{l}\text { Tertiary care } \\
\text { Patients newly admitted to } \\
\text { hospital(tertiary referral centre) } \\
\text { for COPD assessment and } \\
\text { lung transplantation } \\
\text { assessment }\end{array}$ & 16 & $57.9(4.1)$ & $21.1(5.8)$ & - & $\begin{array}{l}\text { Semistructured interview } \\
\text { BPI }\end{array}$ & 38 & $\begin{array}{l}100 \% \\
1.1:+ \\
1.2:+ \\
1.3:+ \\
1.4:+\end{array}$ \\
\hline $\begin{array}{l}\text { Borge et al }\left.\right|^{18 * *} \\
\text { Norway }\end{array}$ & $\begin{array}{l}\text { To explore the relationships } \\
\text { between demographic } \\
\text { and clinical variables and } \\
\text { symptoms for patients with } \\
\text { COPD }\end{array}$ & $\begin{array}{l}\text { Secondary care } \\
\text { Patients recruited from } \\
\text { outpatient pulmonary } \\
\text { department of a hospital }\end{array}$ & 154 & $64.6(10.2)$ & $59.1(22.6)$ & $\begin{array}{l}\text { GOLD } 1: 18.2 \% \\
\text { GOLD } 2: 46.8 \% \\
\text { GOLD } 3: 25.3 \% \\
\text { GOLD } 4: 9.7 \%\end{array}$ & $\begin{array}{l}\text { BPI } \\
\text { HADS } \\
\text { LFS } \\
\text { GSDS } \\
\text { RQLQ }\end{array}$ & - & $\begin{array}{l}75 \% \\
4.1:+ \\
4.2:+ \\
4.3:+ \\
4.4:-\end{array}$ \\
\hline $\begin{array}{l}\text { White } e t a l^{19 * *} \\
\text { UK }\end{array}$ & $\begin{array}{l}\text { To determine the palliative } \\
\text { care needs in patients with } \\
\text { advanced COPD }\end{array}$ & $\begin{array}{l}\text { Primary care } \\
\text { Patients in care of GP's with } \\
\text { diagnosis of COPD, identified } \\
\text { from medical records }\end{array}$ & 145 & $71.6(9.7)$ & 29.1 (9.5) & - & $\begin{array}{l}\text { LLPS } \\
\text { MRC } \\
\text { HADS } \\
\text { CCQ }\end{array}$ & 40 & $\begin{array}{l}100 \% \\
4.1:+ \\
4.2:+ \\
4.3:+ \\
4.4:+\end{array}$ \\
\hline $\begin{array}{l}\text { Janssen et } a^{\Gamma \star *} \\
\text { Netherlands }\end{array}$ & $\begin{array}{l}\text { To assess severity of } \\
\text { symptoms, presence of } \\
\text { comorbidities, and current } \\
\text { provision of healthcare in } \\
\text { outpatients with advanced } \\
\text { COPD or chronic heart failure } \\
\text { (CHF) }\end{array}$ & $\begin{array}{l}\text { Secondary care } \\
\text { Patients recruited from } \\
\text { outpatient pulmonary } \\
\text { department of } 1 \text { academic and } \\
5 \text { general hospitals }\end{array}$ & 105 & $66.3(9.2)$ & $34.1(13.5)$ & $\begin{array}{l}\text { GOLD 1:- } \\
\text { GOLD 2:- } \\
\text { GOLD 3:26.7\% } \\
\text { GOLD } 4: 73.3 \%\end{array}$ & VAS & 32.4 & $\begin{array}{l}100 \% \\
4.1:+ \\
4.2:+ \\
4.3:+ \\
4.4:+\end{array}$ \\
\hline
\end{tabular}


Table 2 Continued

\begin{tabular}{|c|c|c|c|c|c|c|c|c|c|}
\hline Author & Aim & Setting and sample & $\begin{array}{l}N \text { (patients } \\
\text { with COPD) }\end{array}$ & $\begin{array}{l}\text { Mean age in } \\
\text { years (SD) }\end{array}$ & $\begin{array}{l}\mathrm{FEV}_{1} \% \text { of } \\
\text { predicted (SD) }\end{array}$ & GOLD-stage & $\begin{array}{l}\text { Pain, symptom, QoL } \\
\text { instrument used }\end{array}$ & $\begin{array}{l}\text { Outcome (pain } \\
\text { prevalence) (\%) }\end{array}$ & $\begin{array}{l}\text { MMAT } \\
\text { score }\end{array}$ \\
\hline $\begin{array}{l}\text { Bentsen et } a \rho^{\beta * \star} \\
\text { Norway }\end{array}$ & $\begin{array}{l}\text { To evaluate the prevalence } \\
\text { and characteristics of pain in } \\
\text { patients with COPD compared } \\
\text { to a sample from the } \\
\text { Norwegian general population }\end{array}$ & $\begin{array}{l}\text { Secondary care } \\
\text { Patients: sample of patients } \\
\text { with COPD who underwent } \\
\text { outpatient PR programme. } \\
\text { Controls: age appropriate } \\
\text { sample from Norwegian } \\
\text { general population }\end{array}$ & 100 & $65(9.2)$ & $48.0(16.0)$ & $\begin{array}{l}\text { GOLD 1:- } \\
\text { GOLD 2:53\% } \\
\text { GOLD } 3: 31 \% \\
\text { GOLD } 4: 16 \%\end{array}$ & $\begin{array}{l}\text { Screening question: } \\
\text { 'Are you generally bothered } \\
\text { with pain?' } \\
\text { NRS } \\
\text { BPI }\end{array}$ & 45 & $\begin{array}{l}100 \% \\
3.1:+ \\
3.2:+ \\
3.3:+ \\
3.4:+\end{array}$ \\
\hline $\begin{array}{l}\text { Borge et } a^{P^{0 * *}} \\
\text { Norway }\end{array}$ & $\begin{array}{l}\text { To explore the prevalence and } \\
\text { intensity of pain, its location, } \\
\text { how demographic and clinical } \\
\text { variables may be related to } \\
\text { pain and how pain is } \\
\text { associated with QoL }\end{array}$ & $\begin{array}{l}\text { Secondary care } \\
\text { Patients recruited from } \\
\text { outpatient pulmonary } \\
\text { department }\end{array}$ & 154 & $64.6(10.2)$ & $59.1(22.6)$ & $\begin{array}{l}\text { GOLD } 1: 18.2 \% \\
\text { GOLD } 2: 46.8 \% \\
\text { GOLD } 3: 25.3 \% \\
\text { GOLD } 4: 9.7 \%\end{array}$ & $\begin{array}{l}\text { BPI } \\
\text { RQLQ } \\
\text { QOLS }\end{array}$ & 72.1 & $\begin{array}{l}75 \% \\
4.1:+ \\
4.2:+ \\
4.3:+ \\
4.4:-\end{array}$ \\
\hline $\begin{array}{l}\text { Bentsen et } a P^{1 \star *} \\
\text { Norway }\end{array}$ & $\begin{array}{l}\text { To evaluate the differences in } \\
\text { respiratory parameters } \\
\text { between patients with COPD } \\
\text { who did and did not have pain }\end{array}$ & $\begin{array}{l}\text { Secondary care } \\
\text { Sample of patients with COPD } \\
\text { who underwent PR } \\
\text { programme at the outpatient } \\
\text { pulmonary department }\end{array}$ & 100 & $65(9.2)$ & $48.0(16.0)$ & $\begin{array}{l}\text { GOLD 1:- } \\
\text { GOLD 2:53\% } \\
\text { GOLD } 3: 31 \% \\
\text { GOLD } 4: 16 \%\end{array}$ & $\begin{array}{l}\text { Screening question: } \\
\text { 'Are you generally bothered } \\
\text { with pain'? } \\
\text { SGRQ }\end{array}$ & - & $\begin{array}{l}100 \% \\
3.1:+ \\
3.2:+ \\
3.3:+ \\
3.4:+\end{array}$ \\
\hline $\begin{array}{l}\text { Hajghanbari } \\
\text { et } a^{\beta \star \star} \\
\text { Canada }\end{array}$ & $\begin{array}{l}\text { To determinate if pain is more } \\
\text { common in patients with } \\
\text { COPD than in healthy people } \\
\text { and if pain is related to } \\
\text { physical activity, QoL and } \\
\text { comorbidities }\end{array}$ & $\begin{array}{l}\text { Secondary care } \\
\text { Patients recruited from } \\
\text { caseload of respirologists and } \\
\text { PR programmes. Controls } \\
\text { recruited from local population }\end{array}$ & 47 & $70(6.7)$ & $44.7(19.2)$ & - & $\begin{array}{l}\text { MPQ } \\
\text { BPI } \\
\text { TSK } \\
\text { SF-36 }\end{array}$ & 50 & $\begin{array}{l}100 \% \\
3.1:+ \\
3.2:+ \\
3.3:+ \\
3.4:+\end{array}$ \\
\hline $\begin{array}{l}\text { Bentsen et } a^{P^{2 * *}} \\
\text { Norway }\end{array}$ & $\begin{array}{l}\text { To examine the prevalence of } \\
\text { multiple symptoms in patients } \\
\text { with COPD and to examine } \\
\text { the relationship between the } \\
\text { patients outlook for the future } \\
\text { and multiple symptoms }\end{array}$ & $\begin{array}{l}\text { Secondary care } \\
\text { Sample of patients with COPD } \\
\text { who underwent PR } \\
\text { programme at the outpatient } \\
\text { pulmonary department }\end{array}$ & 100 & $66.1(8.3)$ & $46(15)$ & $\begin{array}{l}\text { GOLD } 1:- \\
\text { GOLD } 244 \% \\
\text { GOLD } 3: 43 \% \\
\text { GOLD } 4: 13 \%\end{array}$ & $\begin{array}{l}\text { Screening question: } \\
\text { 'Are you generally bothered } \\
\text { with pain?' } \\
\text { BPQ } \\
\text { NRS }\end{array}$ & - & $\begin{array}{l}100 \% \\
3.1:+ \\
3.2:+ \\
3.3:+ \\
3.4:+\end{array}$ \\
\hline $\begin{array}{l}\text { Roberts et } a^{23 * *} \\
\text { USA }\end{array}$ & $\begin{array}{l}\text { To describe chronic pain } \\
\text { prevalence among patients } \\
\text { with COPD compared with } \\
\text { similar patients with other } \\
\text { chronic diseases in a } \\
\text { managed care population in } \\
\text { the USA }\end{array}$ & $\begin{array}{l}\text { Population based } \\
\text { Cases and controls selected } \\
\text { from members of a regional } \\
\text { managed care plan }\end{array}$ & 7952 & $69.3(-)$ & - & $\begin{array}{l}\text { GOLD } 1: 21.5 \% \\
\text { GOLD } 2: 55.5 \% \\
\text { GOLD } 3: 19.5 \% \\
\text { GOLD } 4: 3.5 \%\end{array}$ & $\begin{array}{l}\text { Identification of pain was } \\
\text { based on both pain diagnosis } \\
\text { and management and was } \\
\text { assessed using diagnosis and } \\
\text { procedure codes from the } \\
\text { managed care claims } \\
\text { database and outpatient } \\
\text { pharmacy information }\end{array}$ & 598 & $\begin{array}{l}100 \% \\
3.1:+ \\
3.2:+ \\
3.3:+ \\
3.4:+\end{array}$ \\
\hline
\end{tabular}

${ }^{*}$ Prospective cohort study; ${ }^{* *}$ cross-sectional study; ${ }^{* * *}$ mixed method; **** retrospective post-bereavement study.

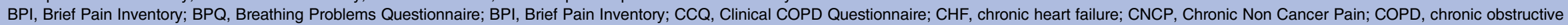
pulmonary disease; DHP, Duke Health Profile; FEV 1 , forced expiratory volume in $1 \mathrm{~s}$; GP, general practitioner; life; GSDS, General Sleep Disturbances Scale; HADS, Hospital Anxiety and Depression Scale; LFS, Lee

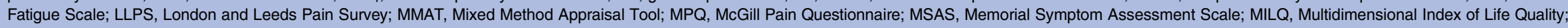
MMAT, Mixed Method Appraisal Tool; MPQ McGill Pain Questionnaire; MRC, Medical Respiratory Counsel dyspnoea scale; MSAS, Memorial Symptom Assessment Scale; NHP, Nottingham Health Profile; NRS,

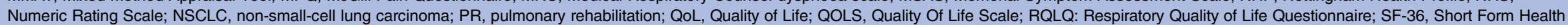
Survey-36; SGRQ, St George Respiratory Questionnaire; SIP, Sickness Impact Profile; TSK, Tampa Scale for Kinesiophobia; VAS, Visual Analogue Scale; SF-36, Short-Form health survey-36; VAS, Visual Analogue Scale; VOICES: VOICES questionnaire. 
(higher scores indicating more pain intensity/interference). Three studies used the body outline diagram of the BPI to investigate the most prominent locations of the experienced pain. ${ }^{9} 17{ }^{20}$ Most frequently reported locations of pain were the shoulders and neck: 33\% $(\mathrm{n}=15),{ }^{9} \quad 36.4 \% \quad(\mathrm{n}=56)^{20}$ and $50 \% \quad(\mathrm{n}=8)^{17}$; lumbar region: $29.2 \%(\mathrm{n}=45)^{20}$ and $47 \% \quad(\mathrm{n}=21)^{9}$ and chest: $17.5 \%(\mathrm{n}=27),{ }^{20} 36 \%(\mathrm{n}=16)^{9}$ and $38 \%(\mathrm{n}=6) .{ }^{17}$ None of the included studies investigated the type of pain (eg, neuropathic or nociceptive pain) or conducted a comprehensive pain assessment.

\section{Factors related to pain}

Of the 14 studies on pain or symptom burden, seven reported factors related to pain or correlations between pain and several variables, such as lung function, comorbidity and other symptoms (table 4 ).

Four of these studies reported from the same two original studies. ${ }^{18}{ }^{20-22}$ None of the studies on pain or symptom burden reported a significant relationship between lung function $\left(\mathrm{FEV}_{1} \%\right.$ predicted, GOLD grade) and pain prevalence or pain severity. Several studies reported a significant correlation between pain and comorbidity. ${ }^{8}{ }^{21} 23$ Bentsen $e t a l^{21}$ reported that comorbidity was a risk factor for pain in patients with COPD; patients with COPD and pain were more likely to report the presence of a comorbidity and had a significantly higher number of comorbidities. However, the study from Borge $e t a l^{20}$ found no significant difference in the number of comorbidities between patients with COPD with and without pain. These conflicting results are also found for the correlation between pain severity and the number of comorbidities ${ }^{8}{ }^{18}$ (table 4). Other variables that showed a significant correlation with pain presence or pain severity are: QoL, breathlessness, insomnia, fatigue, anxiety, depression and nutritional status (table 4). Of the included studies on pain as a subdomain of QoL, none reported correlations between the SF-36_BP score and variables of interest. Two studies using other QoL instruments, that is, the EQ- $5 \mathrm{D}^{40}$ and the $\mathrm{NHP}^{27}$ concluded that their analysis showed no significant correlation between pain as a subdomain of QoL and lung function.

\section{Pain management interventions}

None of the included studies aimed to investigate the effect of a specific intervention on pain in patients with COPD. Bentsen $e t a \theta^{\theta}$ reported that $49 \%$ of the participants with pain received treatment with analgesics and $16 \%$ received physiotherapy. In a cross-sectional study in patients with advanced COPD, Janssen et $a \tilde{\bar{l}}$ found that $47 \%$ of the patients with pain (VAS score $>30 \mathrm{~mm}$ ) reported that their symptoms were addressed. Furthermore, if symptoms were treated, patients reported only moderate satisfaction with symptom treatment. One study on symptom burden in patients with severe COPD in primary care reported that all patients who suffered from pain ever day or pain on most days, were on prescribed analgesics. ${ }^{19}$ Three studies investigated the effect of a pulmonary rehabilitation programme on health status. ${ }^{32-34}$ All reported no effect of the intervention on the pain domain of the health status instrument used (two studies used the SF-36, one used the HSQ).

\section{Overall relationship between pain prevalence and disease severity}

To determine the relationship between lung function and pain prevalence, we calculated the correlation coefficient between these variables. Of the 11 studies that reported on pain prevalence, seven also reported the mean $\mathrm{FEV}_{1} \%$ predicted and one study reported the GOLD grade distribution, ${ }^{23}$ which was converted to a weighted mean GOLD grade (figure 5). There was a strong correlation between lung function $\left(\mathrm{FEV}_{1} \%\right.$ predicted) and pain prevalence; Spearmans $\mathrm{r}=0.79$ ( $p=0.021$ ). Of the 21 studies and groups that reported SF-36/20/8 scores on the pain domain, 18 reported the mean $\mathrm{FEV}_{1} \%$ predicted. In three groups of patients only the GOLD grade was reported, ${ }^{34}{ }^{37}$ which was converted to a weighted mean GOLD grade. No significant correlation was found between the SF-36_BP score and lung function: Pearson's correlation coefficient $=0.21 \quad(p=0.37$; figure 6).

\section{DISCUSSION}

\section{Main findings}

The first main finding of this systematic review is that pain seems to be a significant clinical problem in patients with COPD, with a reported prevalence in highquality studies ranging from $32 \%$ to $60 \%$. Second, literature on pain in patients with is limited; only a few studies with a specific focus on pain in patients with COPD have recently been published. Still, little is known about the causes and characteristics of pain, factors that are related to pain and literature on the effect of interventions aimed at reducing pain in patients with COPD is lacking. Third, our data synthesis shows that studies investigating pain in patients with moderate airflow limitation reported a higher pain prevalence compared with studies in patients with severe airflow limitation. This finding could suggest that pain is more prevalent in patients with moderate COPD compared to patients with severe or very severe COPD. However, confounding and selection bias are likely to occur and much remains unclear about the relation between pain and disease severity. Fourth, our results suggest a correlation between pain and several other symptoms, such as dyspnoea, insomnia, fatigue, anxiety and depression, QoL and comorbidity.

\section{Strengths and limitations}

To our knowledge, this is the first systematic review study on pain in patients with COPD. One strength of this study is that we included all types of studies and used a 
Table 3 Pain as a subdomain of quality of life (QoL)

\begin{tabular}{|c|c|c|c|c|c|c|c|c|c|}
\hline Author & Aim & Setting and sample & $\begin{array}{l}\mathrm{N} \text { (patients with } \\
\text { COPD) }\end{array}$ & $\begin{array}{l}\text { Mean age } \\
\text { (SD) in } \\
\text { years }\end{array}$ & $\begin{array}{l}\mathrm{FEV}_{1} \% \text { of } \\
\text { predicted } \\
\text { (SD) }\end{array}$ & GOLD-stage & $\begin{array}{l}\text { QOL } \\
\text { instrument }\end{array}$ & $\begin{array}{l}\text { Main outcome } \\
\text { (SD) }\end{array}$ & $\begin{array}{l}\text { MMAT } \\
\text { Score }\end{array}$ \\
\hline $\begin{array}{l}\text { Mahler et } a P^{5} \\
(1995)^{\star \star \star \star} \\
\text { USA }\end{array}$ & $\begin{array}{l}\text { To examine longitudinal changes in clinical } \\
\text { parameters in patients with COPD }\end{array}$ & $\begin{array}{l}\text { Secondary care } \\
\text { Patients recruited from the outpatient } \\
\text { pulmonary department of } 3 \text { hospitals }\end{array}$ & 110 & $67(8)$ & $44(17)$ & - & SF-20 & 38.9 (32.9) & $\begin{aligned} 75 \% \\
4.1:+ \\
4.2:+ \\
4.3:+ \\
4.4:-\end{aligned}$ \\
\hline $\begin{array}{l}\text { Mahler et a } R^{4} \\
(1995)^{*} \\
\text { USA }\end{array}$ & $\begin{array}{l}\text { To evaluate the SF- } 36 \text { as an instrument for } \\
\text { measuring HRQoL in patients with } \\
\text { symptomatic COPD }\end{array}$ & $\begin{array}{l}\text { Secondary care } \\
\text { Patients with COPD and no significant } \\
\text { comorbidity recruited from an outpatient } \\
\text { pulmonary department }\end{array}$ & 50 & $72(8)$ & $48.2(21.9)$ & $\begin{array}{l}\text { GOLD } 1: 18 \% \\
\text { GOLD } 2: 20 \% \\
\text { GOLD } 3 \& 4: 62 \%\end{array}$ & SF-36 & $70.5(24.2)$ & $\begin{array}{l}75 \% \\
4.1:+ \\
4.2:+ \\
4.3:+ \\
4.4-\end{array}$ \\
\hline $\begin{array}{l}\text { Hoang Thi et } a f^{26} \\
(1997)^{\star \star \star \star \star} \\
\text { France }\end{array}$ & $\begin{array}{l}\text { To seek factors predicting HRQoL in } \\
\text { patients with severe COPD on LTOT }\end{array}$ & $\begin{array}{l}\text { Primary care } \\
\text { Patients on LTOT monitored at home by a } \\
\text { region organisation for medical assistance } \\
\text { of patients with COPD }\end{array}$ & 61 & $66.0(6.4)$ & - & $\begin{array}{l}\text { GOLD 1:- } \\
\text { GOLD 2:- } \\
\text { GOLD 3\&4:100\% }\end{array}$ & DHP & $46.6(38.1)$ & $\begin{aligned} 75 \% \\
4.1:+ \\
4.2:+ \\
4.3:+ \\
4.4:-\end{aligned}$ \\
\hline $\begin{array}{l}\text { Monso et a } P^{7} \\
(1998)^{*} \\
\text { Spain }\end{array}$ & $\begin{array}{l}\text { To identify physiological parameters related to } \\
\text { QoL in severe patients with COPD using } \\
\text { LTOT }\end{array}$ & $\begin{array}{l}\text { Secondary care } \\
\text { Patients with COPD on LTOT recruited from } \\
\text { outpatient pulmonary department of a } \\
\text { university hospital }\end{array}$ & 47 & $65.2(8.2)$ & $31.8(11.9)$ & $\begin{array}{l}\text { GOLD 1:- } \\
\text { GOLD 2:- } \\
\text { GOLD 3\&4:100\% }\end{array}$ & NHP & $35.1(31.6)$ & $\begin{array}{l}75 \% \\
4.1:+ \\
4.2:+ \\
4.3:+ \\
4.4:-\end{array}$ \\
\hline $\begin{array}{l}\text { Schlenk et } a P^{\text {P }} \\
(1998)^{*} \\
\text { USA }\end{array}$ & $\begin{array}{l}\text { To examine HRQoL as measured by the } \\
\text { SF- } 36 \text { across patient populations with chronic } \\
\text { disorders and to compare QoL in these } \\
\text { participants with normative data on healthy } \\
\text { persons }\end{array}$ & $\begin{array}{l}\text { Primary care } \\
\text { Sample comprised from } 6 \text { studies of } \\
\text { persons with chronic disorders. Patients } \\
\text { with COPD were recruited from a pilot study } \\
\text { designed to determine the effect of } \\
\text { home-based PR on HRQoL }\end{array}$ & 13 & $66.7(3.7)$ & - & - & SF-36 & $58.54(24.16)$ & $\begin{array}{l}25 \% \\
4.1:- \\
4.2:- \\
4.3:+ \\
4.4:-\end{array}$ \\
\hline $\begin{array}{l}\text { Hajiro et a }{ }^{29} \\
(1999)^{\star} \\
\text { Japan }\end{array}$ & $\begin{array}{l}\text { To compare categorisations of the level of } \\
\text { dyspnoea with the staging of disease severity } \\
\text { as defined by the FEV } \mathrm{F}_{1} \text { in representing how } \\
\text { HRQoL is distributed in patients with COPD }\end{array}$ & $\begin{array}{l}\text { Secondary care } \\
\text { Patients ( } 100 \% \text { male) with stable COPD } \\
\text { recruited from outpatient pulmonary } \\
\text { department of a university hospital }\end{array}$ & 194 & $70(8)$ & $41.5(15.6)$ & $\begin{array}{l}\text { GOLD 1:29\% } \\
\text { GOLD 2:32\% } \\
\text { GOLD 3:39\% } \\
\text { GOLD 4:- }\end{array}$ & SF-36 & $65.5(21.3)$ & $\begin{array}{r}100 \% \\
4.1:+ \\
4.2:+ \\
4.3:+ \\
4.4:-\end{array}$ \\
\hline $\begin{array}{l}\text { Stavem et a } \beta^{\beta 0} \\
(1999)^{\star} \\
\text { Norway }\end{array}$ & $\begin{array}{l}\text { To assess relationships between health status } \\
\text { and measures of dyspnoea, lung function and } \\
\text { exercise capacity in patients with COPD }\end{array}$ & $\begin{array}{l}\text { Secondary care } \\
\text { Patients with COPD recruited from } \\
\text { outpatient pulmonary department of a } \\
\text { hospital }\end{array}$ & 59 & 57 (9) & $54(17)$ & $\begin{array}{l}\text { GOLD 1:42\% } \\
\text { GOLD 2:36\% } \\
\text { GOLD 3:22\% } \\
\text { GOLD 4:- }\end{array}$ & SF-36 & $64.0(27.6)$ & $\begin{array}{r}100 \% \\
4.1:+ \\
4.2:+ \\
4.3:+ \\
4.4:+\end{array}$ \\
\hline $\begin{array}{l}\text { Gore et } a^{\beta 1}(2000) \\
\text { UK }\end{array}$ & $\begin{array}{l}\text { To examine if patients with severe COPD are } \\
\text { relatively disadvantaged in terms of medical } \\
\text { and social care compared to patients with } \\
\text { inoperable lung cancer }\end{array}$ & $\begin{array}{l}\text { Secondary care } \\
\text { Patients attending for follow-up at the } \\
\text { outpatient pulmonary department of a } \\
\text { hospital }\end{array}$ & 50 & $70.5(5.5)$ & - & $\begin{array}{l}\text { GOLD 1:- } \\
\text { GOLD 2:- } \\
\text { GOLD 3\&4:100\% }\end{array}$ & SF-36 & $\begin{array}{l}\text { (only figures } \\
\text { presented) }\end{array}$ & $\begin{array}{r}100 \% \\
4.1:+ \\
4.2:+ \\
4.3:+ \\
4.4:+\end{array}$ \\
\hline $\begin{array}{l}\text { Kaelin et } a^{\beta 2} \\
(2001)^{\star \star \star} \\
\text { USA }\end{array}$ & $\begin{array}{l}\text { To examine the efficacy of a programme using } \\
\text { symptom limited interval training combined } \\
\text { with strength training on } 6 \mathrm{MWT} \text {, increases in } \\
\text { exercise capacity and QoL }\end{array}$ & $\begin{array}{l}\text { Secondary care } \\
\text { Patients with primary diagnosis of COPD } \\
\text { entering a PR programme at an outpatient } \\
\text { pulmonary department }\end{array}$ & 50 & $68.4(6.9)$ & $39.5(11.5)$ & - & $\mathrm{HSQ}$ & $\begin{array}{l}\text { pre-PR: } \\
65.9(26.7) \\
\text { post-PR: } \\
69.5(21.6) \\
\text { NS }\end{array}$ & $\begin{array}{l}50 \% \\
4.1:+ \\
4.2:+ \\
4.3:- \\
4.4:-\end{array}$ \\
\hline
\end{tabular}




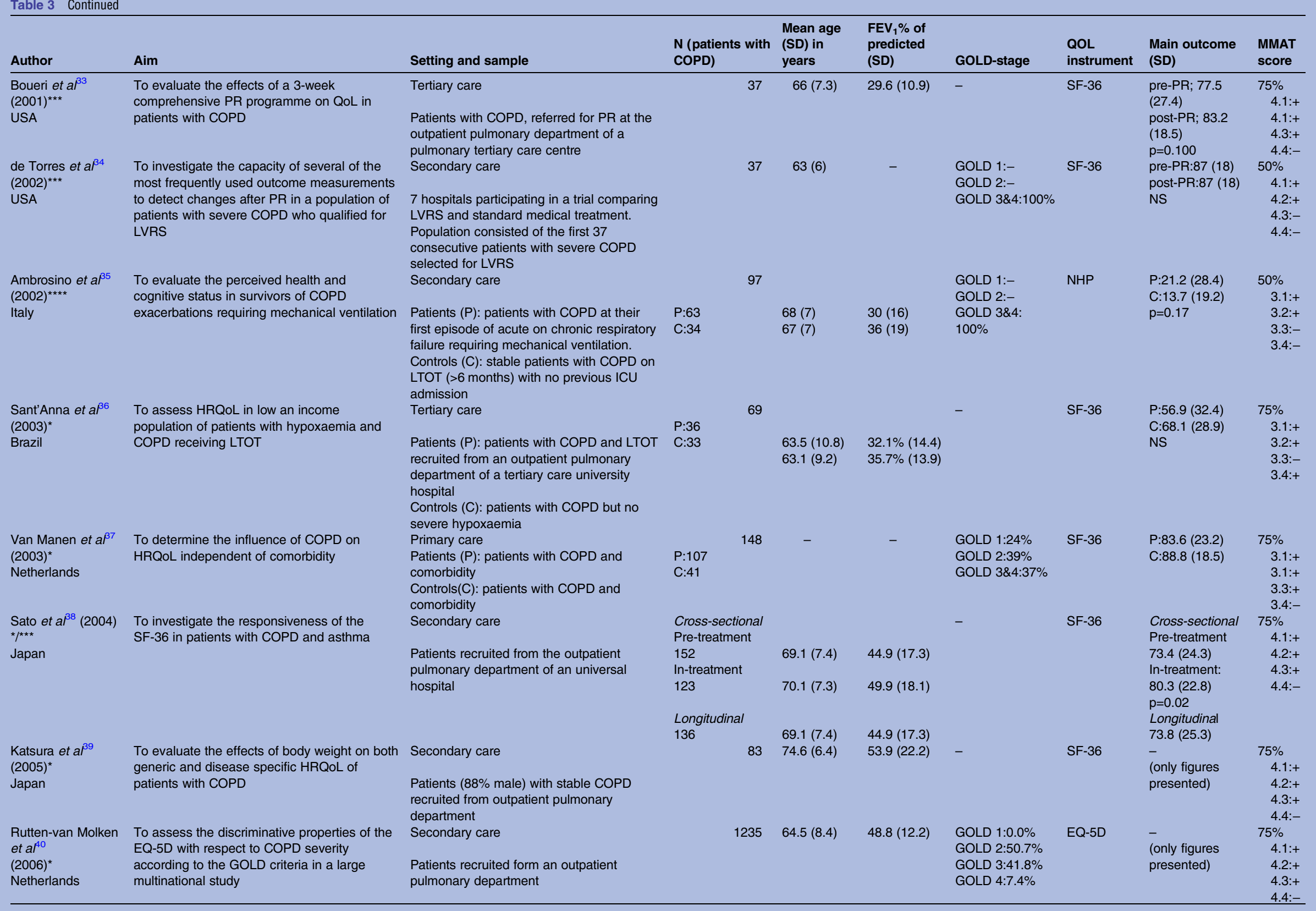

Continued 


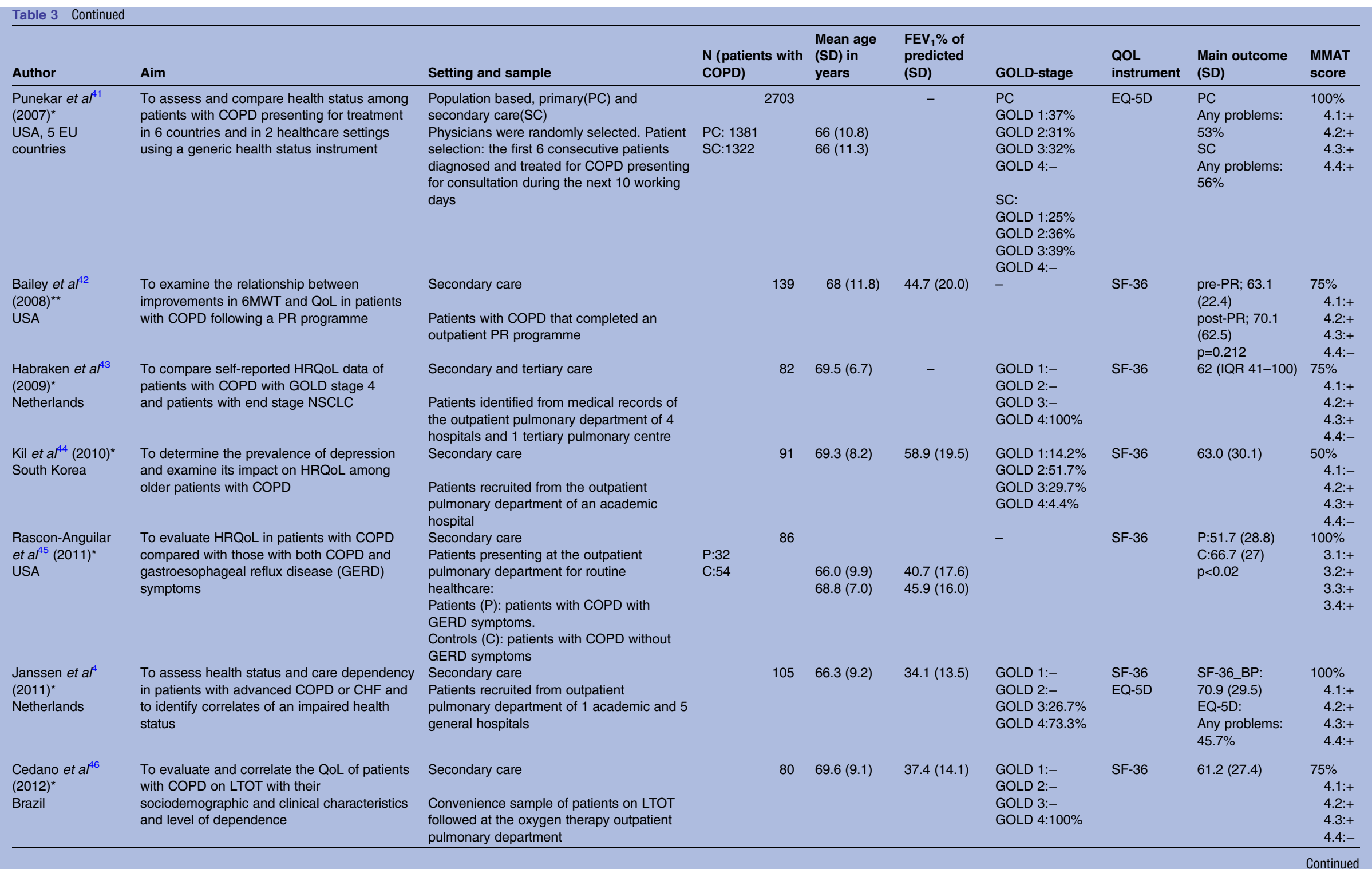




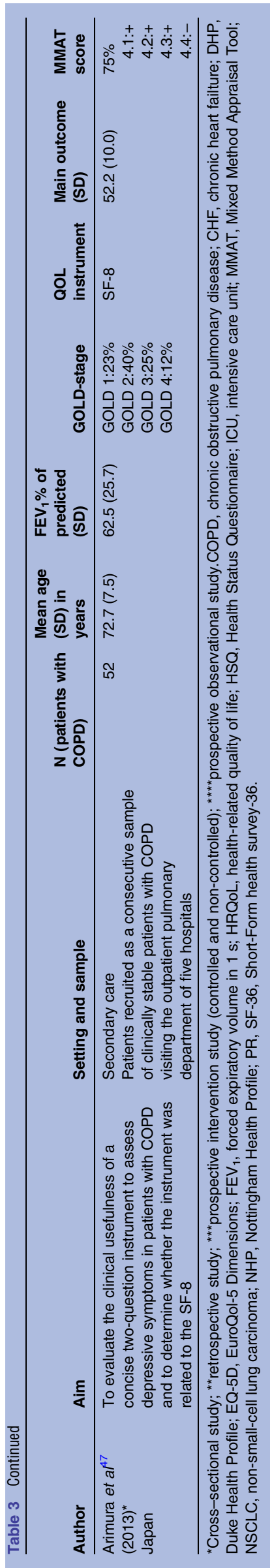

broad search method. Therefore, it seems unlikely that the search strategy we used failed to identify relevant published studies. Second, the selection strategy was objective, as it was performed by two, and in case of disagreement, by three individual members of the review team. Third, we were able to conduct a meta-analysis on the SF-36_BP data.

Some limitations also need to be discussed. First, as literature on this topic is scarce, only 14 studies on pain and symptom burden in patients with COPD were included. Moreover, these studies showed substantial heterogeneity in design, setting, patient characteristics and pain measurement instruments used. Selected studies included patients with relatively severe COPD; mean $\mathrm{FEV}_{1} \%$ predicted ranged from $21 \%$ to $48 \%$. These differences in study methods might have influenced the reported pain prevalence and also limit the generalisability of the results. Furthermore, there were differences between the studies in patient selection criteria and the healthcare setting from which the patients were recruited, although most of the studies were conducted in a secondary (outpatient) care setting. Second, the appropriateness of including the SF-36_BP scores in this review is debatable. As our search strategy did not include 'QoL' as a keyword, we included only those studies on QoL that mentioned the keyword 'pain' in the abstract. This implies that our data on pain as a subdomain of QoL may not be complete. Nevertheless, we feel that the reported results do provide important information on this subject.

\section{Interpretation of findings and relation to other literature}

The wide range in pain prevalence can be explained by the heterogeneity in study design, setting, patient characteristics and instruments and definitions used to measure pain. We were interested in chronic and/or recurrent pain in patients with COPD. However, as we wanted a broad search method, we used 'pain' instead of 'chronic pain' as a major key word in our search strategy, as many studies do not clearly define pain as being 'chronic' or 'acute'. We did however exclude studies that concerned 'pain during acute bronchitis' (figure 1). Different studies used different definitions of pain and none of the included studies presented longitudinal data on the course of pain. The wide range in pain prevalence can also be explained by differences in the quality assessment score. Three of the studies on pain and symptom burden that reported the prevalence of pain, had quality limitations as identified with the MMAT. Furthermore, in the study conducted by Elkington $e a^{14}$ pain prevalence was based on reports of informants of the deceased participants. Agreement between the patient's and the proxy perception of pain is only moderate. ${ }^{14} 49$ This by-proxy reporting of symptoms and the fact that the study included only patients in the terminal phase of their disease, could explain the relatively high level of reported prevalence of pain $(72 \%)$. Claessens et $a l^{13}$ reported a relatively low 
Figure 2 Number of publications on 'pain' and 'symptom burden including pain' in patients with chronic obstructive pulmonary disease.

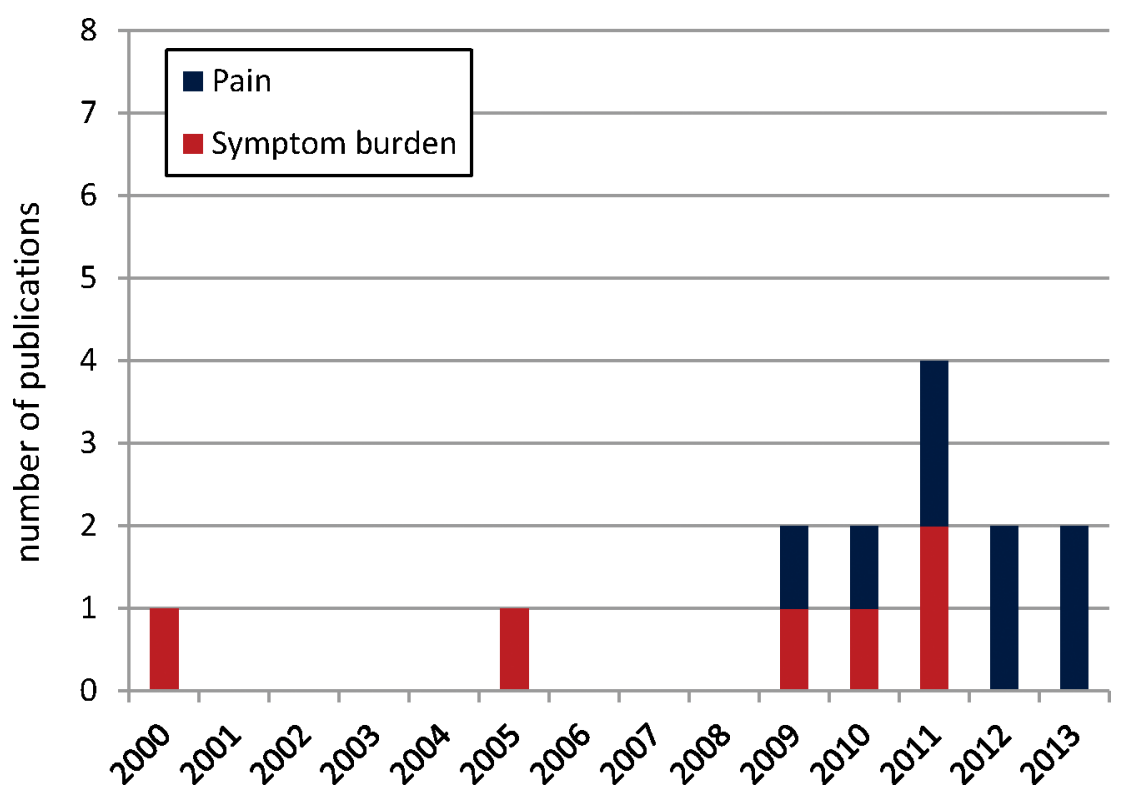

prevalence of pain $(21 \%)$. However, pain was defined as 'moderately severe or extremely severe pain at least half of the time'. Borge $e t a l^{20}$ found a relatively high prevalence $(72 \%)$ but used a much lower threshold, as pain was considered to be present in all patients that shaded pain on the body diagram of the BPI. Roberts et $a l^{23}$ also reported a relatively high pain prevalence of $60 \%$. In their cross-sectional study, recurrent pain-related healthcare utilisation (diagnosis and treatment) was considered evidence of chronic pain; data were received from the managed care claims database and from the outpatient pharmacy. Although evidence of chronic pain based on diagnosis and management can be reliable, it should be noted that, in the latter study, $28.6 \%$ patients with COPD used short-acting or long-acting opioids, compared with $17 \%$ in the control group (patients with other chronic diseases). ${ }^{23}$ However, as the reason for prescribing opioids was not stated it is debatable whether opioid prescription was indeed aimed at treating pain, especially as it is also prescribed for chronic dyspnoea in patients with COPD. ${ }^{50}$ Therefore, the reported prevalence of chronic pain in the study of Roberts $e t a l^{23}$ might be an overestimation. The reported prevalence of pain should be interpreted in relation to pain prevalence in the general population, as well as in patients with cancer and other chronic diseases. Recent population-based surveys showed that $25-35 \%$ of the adults report chronic pain. ${ }^{51}$ In patients with cancer this percentage is higher, as $50 \%$ of all patients with cancer experience chronic pain. ${ }^{51}$ Thus, the literature indicates that the prevalence of pain in patients with COPD is higher compared with the general population. Results from our meta-analysis on the SF-36_BP data also show that patients with COPD experience more pain compared to the general population: mean score of the SF-36_BP domain in the general US adult population is 75.2 (SD 23.7) ${ }^{11}$ which is higher than the mean score we found in our random-effects meta-analysis of the SF-36_BP data in patients with COPD. A higher score on the SF-36_BP domain refers to less pain and better QoL. We were not able to perform a meta-analysis on the results of the included studies that used other QoL
Figure 3 Prevalence of pain. prospective cohort study; cross-sectional study; - mixed method; $\Delta$ retrospective postbereavement study. green: Mixed Method Appraisal Tool (MMAT)-score: $100 \%$; orange: MMAT-score: $75 \%$; red: MMAT-score: $50 \%$.

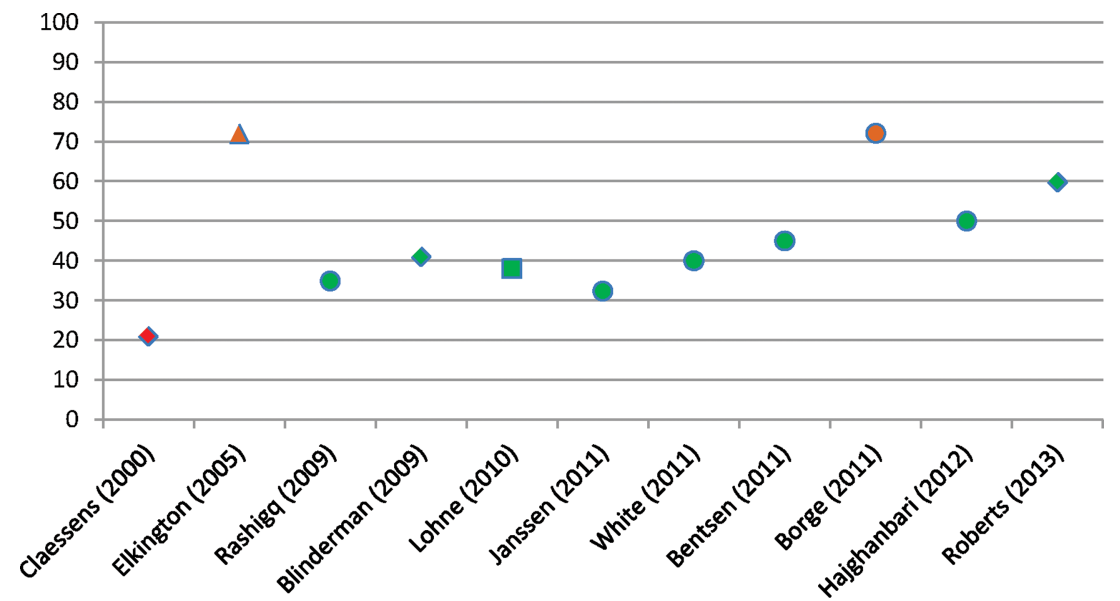


Figure 4 Random effects meta-analysis of studies that examined the mean score on Short-Form health survey-36 (SF-36_BP) in patients with chronic obstructive pulmonary disease. The Forest plot shows the mean scores with $95 \%$ Cls for included study populations. The $Q$ statistic was 19.32 with $\mathrm{df}=20$ ( $p>0.10)$ and $\mathrm{I}^{2}$ was $0 \%$. The MMAT scores are shown using different colours: green:

MMAT-score: $100 \%$; orange:

MMAT-score: 75\%; red:

MMAT-score: $50 \%$; purple:

MMAT-score: $25 \%$.

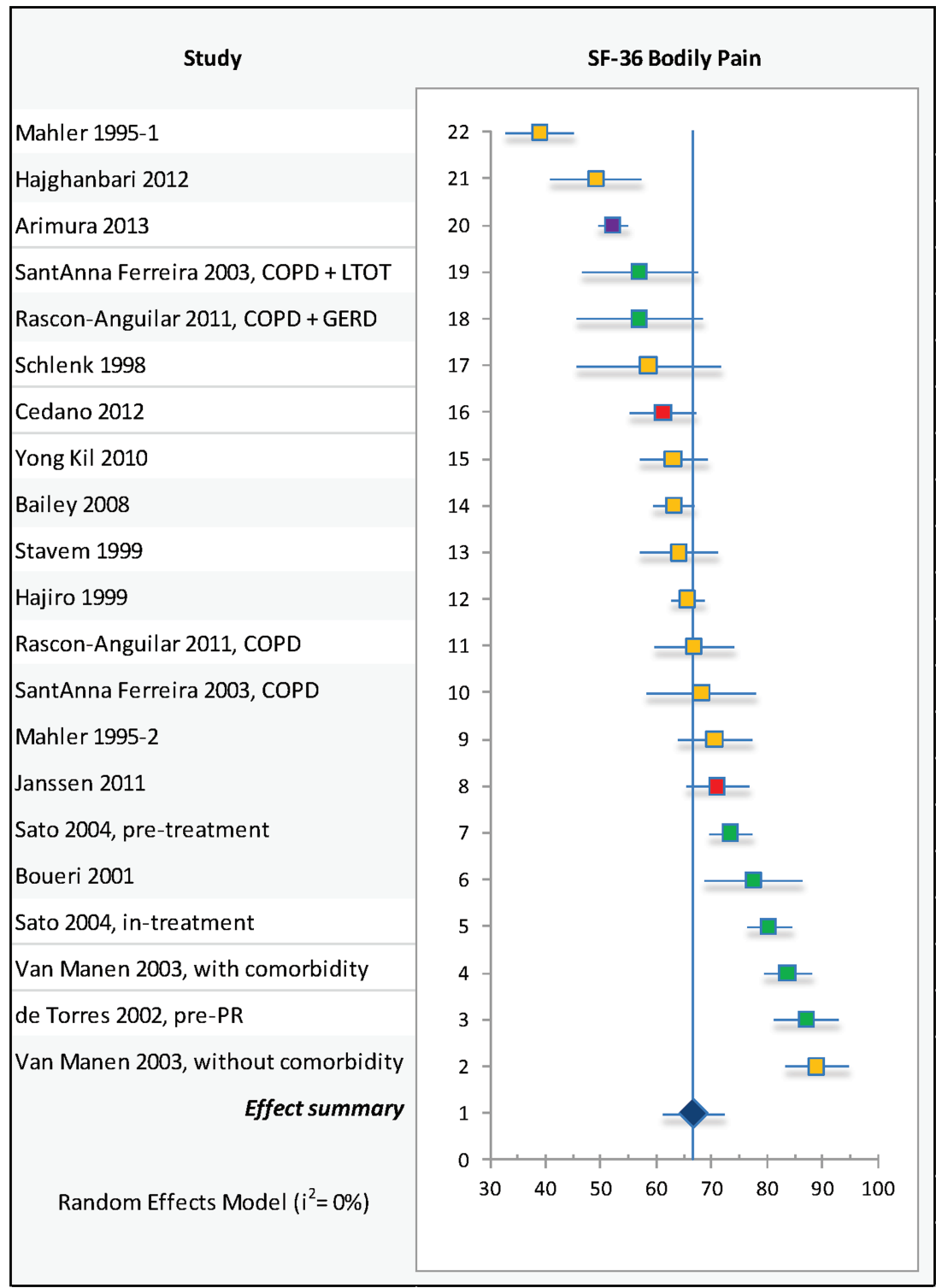

instruments, because of the very small numbers of studies that used the same instrument (EQ-5D: $n=3$; NHP: $n=2$; HSQ: $n=1$; DHP: $n=1$ ). Results from the random-effects meta-analysis of the SF-36_BP scores show substantial heterogeneity. It is very likely, that parts of the heterogeneity is explained by research setting, population, study design, cultural diversity and other, unknown variables.

None of the included studies on pain or symptom burden reported a significant relationship between lung function (measured as $\mathrm{FEV}_{1} \%$ predicted or GOLD grade) and pain prevalence or pain severity.

Table 4 Factors related to pain (presence and severity)

\begin{tabular}{|c|c|c|}
\hline Significant relation & No relation & Conflicting results \\
\hline $\begin{array}{l}\text { HRQoL }^{20} \\
\text { Breathlessness }^{171821} \\
\text { Insomnia }^{1822} \\
\text { Fatigue }^{18} \\
\text { Anxiety }^{18} \\
\text { Depression }^{1823} \\
\text { Nutritional status }^{20}\end{array}$ & $\begin{array}{l}\text { age, sex }{ }^{1820-22} \\
\text { Lung function }^{8} 1820-23 \\
\text { Smoking status }^{182021}\end{array}$ & Comorbidity $^{8} 18$ 20-23 \\
\hline
\end{tabular}




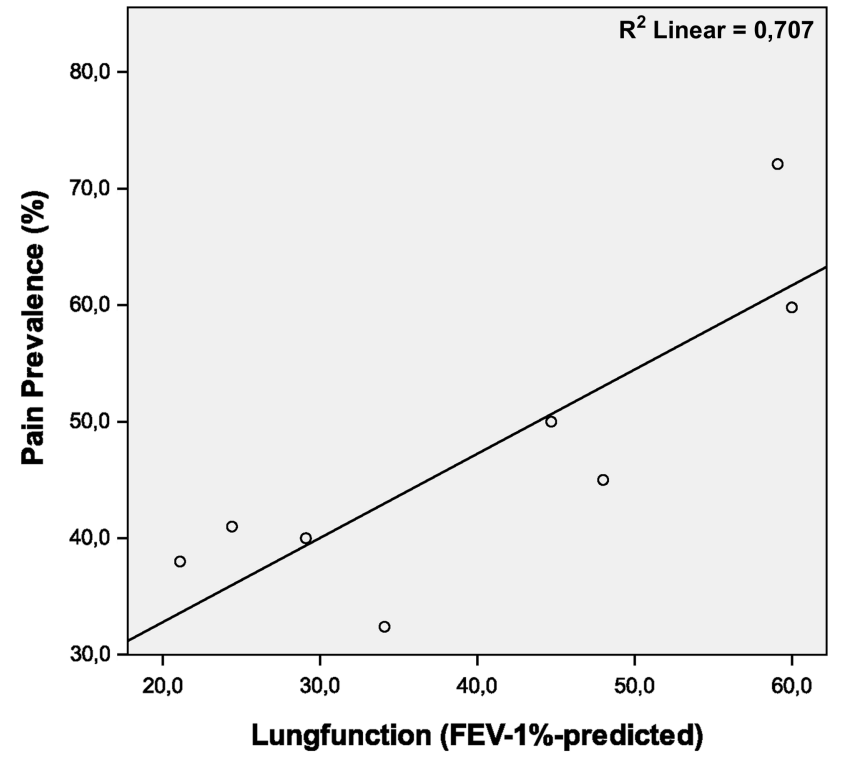

Figure 5 Relationship between lungfunction and pain prevalence. Each data point represents a separate study. Correlation coefficient: Spearmans $r=0.79(p=0.021)$.

Interestingly, when we investigated the correlation between lung function and pain prevalence over all included studies on pain and symptom burden in patients with COPD, a strong correlation was found between lung function and pain prevalence. Studies that investigated prevalence of pain in patients with moderate COPD reported a higher pain prevalence compared with studies in patients with severe and very severe

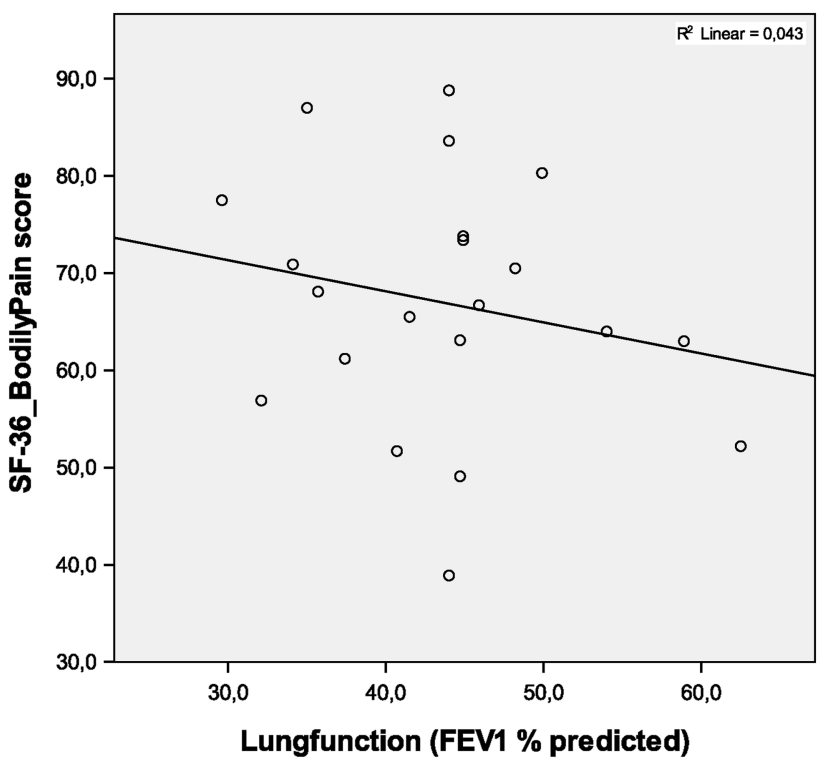

Figure 6 Relationship between lungfunction and Short-Form health survey-36 Bodily Pain (SF-36_BP) score. Each data point represents a separate study. Increasing units on the $y$-axis (eg, higher SF-36_BP scores) refer to less severe pain and better quality of life. Pearson's correlation coefficient $=0.21$ $(p=0.37)$.
COPD. This might suggest that pain is more prevalent in patients with moderate COPD compared with patients with severe or very severe COPD. This finding has not previously been reported in literature on pain in patients with COPD. An explanation for this might be found in the hypothesis that when investigating the relationship between lung function and pain, confounding and selection bias are very likely to occur. Possible selection bias and confounding in the included studies might be an explanation for the observed relation between lung function and pain prevalence in the present study. For example, the number and severity of comorbidities may have caused selection bias: patients with very severe COPD and many comorbidities (cardiovascular and musculoskeletal such as osteoporosis) might have already died, or were not able to participate in the studies due to severely limited functional capacity. The number and severity of comorbidities might also have acted as a confounder in the relationship between pain prevalence and disease severity in the included studies. Furthermore, our results can be interpreted in line with a growing body of evidence showing that the correlation between $\mathrm{FEV}_{1}$, symptoms and impairment of a patient's health status is weak. ${ }^{52}$ Hence, in the recently updated GOLD Global Strategy for Diagnosis, Management and Prevention of COPD (GOLD strategy, 2014) the classification of a patient's disease severity requires assessment of symptoms and exacerbation history, in addition to the degree of airflow obstruction. Our results show some evidence for a relationship between pain and comorbidity, although the included studies are not entirely consistent on this topic. Musculoskeletal disorders and comorbidities (including mechanical limitations of chest wall movement due to hyperinflation and osteoporosis) are considered possible causes of pain in patients with COPD. ${ }^{8}$ However, due to the heterogeneity in the study designs we were unable to conduct a meta-analysis on pain prevalence and lung function controlling for comorbidity. In conclusion, much remains unclear about the relationship between disease severity, pain and comorbidity in patients with COPD and further research on this topic is needed.

We were unable to identify a study that investigated a specific intervention aimed at reducing pain in patients with COPD. The lack of literature on this topic is probably due to the fact that, in general, literature on pain in patients with COPD is scarce and pain seems to be a symptom that is often overlooked; this applies to daily practice and to research on the effect of comprehensive interventions, such as pulmonary rehabilitation (PR) and integrated disease management (IDM). In systematic reviews on PR and IDM in patients with COPD, pain is not mentioned as a patient-centred outcome in the field of symptom management. ${ }^{53} 54$ Also, in national and international COPD guidelines there is almost no discussion of pain as part of a comprehensive symptom assessment. For example, the GOLD Global Strategy for Diagnosis, Management, and Prevention of COPD 
(GOLD guideline 2014) does not mention chronic pain and discusses opioids only in the context of the relief of dyspnoea. Also, the combined statement on PR of two major international medical societies does not mention pain as a problem in COPD management. ${ }^{55}$ Moreover in the Institute for Clinical Systems Improvement (ISCI) guidelines for management of COPD, pain is not discussed. Only the American Thoracic Society (ATS) clinical policy statement on palliative care for patients with respiratory diseases and critical illness includes a separate section on pain management; however, this addresses only dying patients with respiratory diseases and critical illnesses in general. ${ }^{56}$

\section{CONCLUSION AND IMPLICATIONS}

Pain in patients with COPD is a significant problem with an estimated prevalence of $32-60 \%$. Literature on this topic is scare, and studies specifically focusing on pain in patients with COPD have only recently been published. Little is known about the factors associated with pain and no literature is available on the effect of interventions aimed at reducing pain in patients with COPD. Studies that investigated pain in patients with moderate airflow limitation reported a higher pain prevalence compared with studies in patients with severe and very severe airflow limitation. This finding might suggest that pain is more prevalent in patients with moderate COPD compared with patients with severe or very severe COPD. However, there was a substantial heterogeneity in patient characteristics and outcome assessment tools. More research on this topic is needed. Standardisation of assessment tools of pain in patients with COPD is needed. Future studies should focus on determining a more accurate prevalence of pain in patients with COPD, also in relationship to disease severity and comorbidity. Research should also pay more attention to the causes, course and characteristics of pain and clinical intervention trials are warranted. Furthermore, adequate pain recognition and treatment in clinical practice is important and pain assessment should be incorporated into regular comprehensive symptom assessment in the clinical care of this group of patients. Finally, pain prevalence and its possible impact on QoL should be discussed in guidelines on COPD in order to raise awareness and recognition of this topic.

Contributors EFvDvl, KHG-S and DJAJ selected the studies. EFvDvl wrote the manuscript. KHG-S, MS-vE, MWMW, DJAJ, NHC and WPA reviewed and helped writing the manuscript. All authors contributed to the design of the study.

Funding EFvDvl is financially supported by Zorggroep Solis, Deventer, the Netherlands. Zorggroep Solis is the long-term care facility at which EFvDvl works as elderly care physician.

Competing interests None.

Provenance and peer review Not commissioned; externally peer reviewed.

Data sharing statement No additional data are available.
Open Access This is an Open Access article distributed in accordance with the Creative Commons Attribution Non Commercial (CC BY-NC 4.0) license, which permits others to distribute, remix, adapt, build upon this work noncommercially, and license their derivative works on different terms, provided the original work is properly cited and the use is non-commercial. See: http:// creativecommons.org/licenses/by-nc/4.0/

\section{REFERENCES}

1. Viegi G, Pistelli F, Sherrill DL, et al. Definition, epidemiology and natural history of COPD. Eur Respir J 2007;30:993-1013.

2. Chapman KR, Mannino DM, Soriano JB, et al. Epidemiology and costs of chronic obstructive pulmonary disease. Eur Respir J 2006;27:188-207.

3. Habraken JM, van der Wal WM, Ter Riet G, et al. Health-related quality of life and functional status in end-stage COPD: a longitudinal study. Eur Respir J 2011;37:280-8.

4. Janssen DJA, Franssen FME, Wouters EFM, et al. Impaired health status and care dependency in patients with advanced COPD or chronic heart failure. Qual Life Res 2011;20:1679-88.

5. Janssen DJ, Spruit MA, Uszko-Lencer NH, et al. Symptoms, comorbidities, and health care in advanced chronic obstructive pulmonary disease or chronic heart failure. J Palliat Med 2011;14:735-43.

6. Janssen DJ, Spruit MA, Wouters EF, et al. Daily symptom burden in end-stage chronic organ failure: a systematic review. Palliat Med 2008;22:938-48.

7. Solano JP, Gomes B, Higginson IJ. A comparison of symptom prevalence in far advanced cancer, AIDS, heart disease, chronic obstructive pulmonary disease and renal disease. J Pain Symptom Manage 2006;31:58-69.

8. HajGhanbari B, Holsti L, Road JD, et al. Pain in people with chronic obstructive pulmonary disease (COPD). Respir Med 2012;106:998-1005.

9. Bentsen SB, Rustoen T, Miaskowski C. Prevalence and characteristics of pain in patients with chronic obstructive pulmonary disease compared to the Norwegian general population. $J$ Pain 2011;12:539-45.

10. Pluye P. Critical appraisal tools for assessing the methodological quality of qualitative, quantitative and mixed methods studies included in systematic mixed studies reviews. J Eval Clin Pract 2013;19:722.

11. Ware JE, Jr., Sherbourne CD. The MOS 36-item short-form health survey (SF-36). I. Conceptual framework and item selection. Med Care 1992;30:473-83.

12. Neyeloff JL, Fuchs SC, Moreira LB. Meta-analyses and Forest plots using a microsoft excel spreadsheet: step-by-step guide focusing on descriptive data analysis. BMC Res Notes 2012;5:52.

13. Claessens MT, Lynn J, Zhong Z, et al. Dying with lung cancer or chronic obstructive pulmonary disease: insights from SUPPORT. Study to Understand Prognoses and Preferences for Outcomes and Risks of Treatments. J Am Geriatr Soc 2000;48(5 Suppl):S146-53.

14. Elkington $\mathrm{H}$, White $\mathrm{P}$, Addington-Hall J, et al. The healthcare needs of chronic obstructive pulmonary disease patients in the last year of life. Palliat Med 2005;19:485-91.

15. Rashiq S, Dick BD. Factors associated with chronic noncancer pain in the Canadian population. Pain Res Manag 2009;14:454-60.

16. Blinderman CD, Homel $P$, Billings JA, et al. Symptom distress and quality of life in patients with advanced chronic obstructive pulmonary disease. J Pain Symptom Manage 2009;38:115-23.

17. Lohne V, Heer HC, Andersen M, et al. Qualitative study of pain of patients with chronic obstructive pulmonary disease. Heart Lung 2010;39:226-34.

18. Borge CR, Wahl AK, Moum T. Association of breathlessness with multiple symptoms in chronic obstructive pulmonary disease. $J \mathrm{Adv}$ Nurs 2010;66:2688-700.

19. White $\mathrm{P}$, White $\mathrm{S}$, Edmonds $\mathrm{P}$, et al. Palliative care or end-of-life care in advanced chronic obstructive pulmonary disease: a prospective community survey. Br J Gen Pract 2011;61:e362-70.

20. Borge CR, Wahl AK, Moum T. Pain and quality of life with chronic obstructive pulmonary disease. Heart Lung 2011;40:e90-101.

21. Bentsen SB, Rustoen T, Miaskowski C. Differences in subjective and objective respiratory parameters in patients with chronic obstructive pulmonary disease with and without pain. Int J Chron Obstruct Pulmon Dis 2012;7:137-43.

22. Bentsen S, Gundersen D, Assmus J, et al. Multiple symptoms in patients with chronic obstructive pulmonary disease in Norway. Nurs Health Sci 2013;15:292-9. 
23. Roberts $\mathrm{MH}$, Mapel DW, Hartry A, et al. Chronic pain and pain medication use in chronic obstructive pulmonary disease: a cross-sectional study. Ann Am Thorac Soc 2013;10:290-8.

24. Mahler DA, Mackowiak JI. Evaluation of the short-form 36-item questionnaire to measure health-related quality of life in patients with COPD. Chest 1995;107:1585-9.

25. Mahler DA, Tomlinson D, Olmstead EM, et al. Changes in dyspnea, health status, and lung function in chronic airway disease. $A m \mathrm{~J}$ Respir Crit Care Med 1995;151:61-5.

26. Hoang Thi TH, Guillemin F, Cornette A, et al. Health-related quality of life in long-term oxygen-treated chronic obstructive pulmonary disease patients. Lung 1997;175:63-71.

27. Monso E, Fiz JM, Izquierdo J, et al. Quality of life in severe chronic obstructive pulmonary disease: correlation with lung and muscle function. Respir Med 1998;92:221-7.

28. Schlenk EA, Erlen JA, Dunbar-Jacob J, et al. Health-related quality of life in chronic disorders: a comparison across studies using the MOS SF-36. Qual Life Res 1998;7:57-65.

29. Hajiro T, Nishimura K, Tsukino M, et al. A comparison of the level of dyspnea vs disease severity in indicating the health-related quality of life of patients with COPD. Chest 1999;116:1632-7.

30. Stavem K, Boe J, Erikssen J. Health status, dyspnea, lung function and exercise capacity in patients with chronic obstructive pulmonary disease. Int J Tuberc Lung Dis 1999;3:920-6.

31. Gore JM, Brophy CJ, Greenstone MA. How well do we care for patients with end stage chronic obstructive pulmonary disease (COPD)? A comparison of palliative care and quality of life in COPD and lung cancer. Thorax 2000;55:1000-6.

32. Kaelin ME, Swank AM, Barnard KL, et al. Physical fitness and quality of life outcomes in a pulmonary rehabilitation program utilizing symptom limited interval training and resistance training $J$ Exerc Physiol Online 2001;4:30-7.

33. Boueri FM, Bucher-Bartelson BL, Glenn KA, et al. Quality of life measured with a generic instrument (Short Form-36) improves following pulmonary rehabilitation in patients with COPD. Chest 2001;119:77-84

34. de Torres JP, Pinto-Plata V, Ingenito E, et al. Power of outcome measurements to detect clinically significant changes in pulmonary rehabilitation of patients with COPD. Chest 2002;121:1092-8

35. Ambrosino N, Bruletti G, Scala V, et al. Cognitive and perceived health status in patient with chronic obstructive pulmonary disease surviving acute on chronic respiratory failure: a controlled study. Intensive Care Med 2002;28:170-7.

36. Sant'Anna CA, Stelmach R, Zanetti Feltrin MI, et al. Evaluation of health-related quality of life in low-income patients with COPD receiving long-term oxygen therapy. Chest 2003;123: 136-41.

37. van Manen JG, Bindels PJ, Dekker FW, et al. The influence of COPD on health-related quality of life independent of the influence of comorbidity. J Clin Epidemiol 2003;56:1177-84.

38. Sato $\mathrm{S}$, Nishimura $\mathrm{K}$, Tsukino $\mathrm{M}$, et al. Possible maximal change in the SF-36 of outpatients with chronic obstructive pulmonary disease and asthma. J Asthma 2004;41:355-65.

39. Katsura H, Yamada K, Kida K. Both generic and disease specific health-related quality of life are deteriorated in patients with underweight COPD. Respir Med 2005;99:624-30.
40. Rutten-van Molken MP, Oostenbrink JB, Tashkin DP, et al. Does quality of life of COPD patients as measured by the generic EuroQol five-dimension questionnaire differentiate between COPD severity stages? Chest 2006;130:1117-28.

41. Punekar YS, Rodriguez-Roisin R, Sculpher M, et al. Implications of chronic obstructive pulmonary disease (COPD) on patients' health status: a western view. Respir Med 2007;101:661-9.

42. Bailey SP, Brown L, Bailey EK. Lack of relationship between functional and perceived quality of life outcomes following pulmonary rehabilitation. Cardiopulm Phys Ther J 2008;19:3-10.

43. Habraken JM, ter Riet G, Gore JM, et al. Health-related quality of life in end-stage COPD and lung cancer patients. J Pain Symptom Manage 2009;37:973-81.

44. Kil SY, Oh WO, Koo BJ, et al. Relationship between depression and health-related quality of life in older Korean patients with chronic obstructive pulmonary disease. J Clin Nurs 2010;19:1307-14.

45. Rascon-Aguilar IE, Pamer M, Wludyka P, et al. Poorly treated or unrecognized GERD reduces quality of life in patients with COPD. Dig Dis Sci 2011;56:1976-80.

46. Cedano S, Belasco AG, Traldi F, et al. Influence that sociodemographic variables, clinical characteristics, and level of dependence have on quality of life in COPD patients on long-term home oxygen therapy. J Bras Pneumol 2012;38:331-8.

47. Arimura Y, Yamazaki S, Yanagi S, et al. Clinical usefulness of the two-question assessment tool for depressive symptoms in Japanese patients with chronic obstructive pulmonary disease. Lung 2013;191:101-7.

48. Tan G, Jensen MP, Thornby Jl, et al. Validation of the Brief Pain Inventory for chronic nonmalignant pain. J Pain 2004;5:133-7.

49. Janssen DJ, Spruit MA, Wouters EF, et al. Symptom distress in advanced chronic organ failure: disagreement among patients and family caregivers. J Palliat Med 2012;15:447-56.

50. Ekstrom MP, Bornefalk-Hermansson A, Abernethy AP, et al. Safety of benzodiazepines and opioids in very severe respiratory disease: national prospective study. BMJ 2014;348:g445.

51. Breivik H, Eisenberg E, O'Brien T. The individual and societal burden of chronic pain in Europe: the case for strategic prioritisation and action to improve knowledge and availability of appropriate care. BMC Public Health 2013;13:1229.

52. Jones PW. Health status and the spiral of decline. COPD 2009;6:59-63.

53. Kruis AL, Smidt N, Assendelft WJ, et al. Integrated disease management interventions for patients with chronic obstructive pulmonary disease. Cochrane Database Syst Rev 2013;10:CD009437.

54. Lacasse Y, Martin S, Lasserson TJ, et al. Meta-analysis of respiratory rehabilitation in chronic obstructive pulmonary disease. A Cochrane systematic review. Eura Medicophys 2007;43:475-85.

55. Spruit MA, Singh SJ, Garvey C, et al. An official American Thoracic Society/European Respiratory Society statement: key concepts and advances in pulmonary rehabilitation. Am J Respir Crit Care Med 2013;188:e13-64.

56. Lanken PN, Terry PB, Delisser HM, et al. An official American Thoracic Society clinical policy statement: palliative care for patients with respiratory diseases and critical illnesses. Am J Respir Crit Care Med 2008;177:912-27. 